Onofrei, C. \& Smith, R.B. 1985. A land productivity assessment procedure using simulation techniques. Department of Soil Science, University of Manitoba, Winnipeg.

Peters, T.W. 1981. Crop yields in Alberta. Relationships to soil capability for agriculture and soil type. Alberta Institute of Pedology, Edmonton.

Pierce, F.J., Larson, W.E., Dowdy, R.H. \& Graham, W.A.P. 1983. Productivity of soils: assessing long-term changes due to erosion. Fournal of Soil and Water Conservation 38, 39-44.

Rijsberman, F.R. \& Wolman, M.G. 1985. Effects of erosion on soil productivity: An international comparison. Fournal of Soil and Water Conservation 40, 349-354.

Riquier, J. 1974. A summary of parametric methods in soil and land evaluation. In: Approaches to land classification. FAO Soils Bulletin No. 22, FAO, Rome.

Shields, J.A. \& Ferguson, W.S. 1975. Land resources, production possibilities and limitations for crop production in the prairie provinces. In: Oilseed and Pulse Crops in Western Canada - A Symposium (Ed. J.T. Harapiak), pp.115-157. Modern Press, Saskatoon.

Smit, B., Brklacich, M., Dumanski, J., MacDonald, K.B. \& Miller, M.H. 1984. Integral land evaluation and its application to policy. Canadian fournal Soil Science 64, 467-479.

Soil Conservation Service, 1983. Soil potential ratings. Part 603.09. In: National soils Handbook. Soil Conservation Service, Washington.
Stewart, R.B. 1983. Modelling methodology for assessing crop production potentials in Canada. Research Branch Agriculture Canada, Ottawa.

Thompson, L.M. 1975. Weather variability, climate change and grain production. Science 188, 535-541.

Thompson, L.M. 1985. Weather variability, climate change and soybean production. Fournal of Soil Conservation 40, 386-389.

Weir, A.H., Bragg, P.L., Porter J.R. \& Rayner, J.H. 1984. A winter wheat crop simulation model without water or nutrient limitations. Foumal of Agricultural Science, Cambridge 102, 311-382.

Williams, G.D.V. 1973. Estimates of prairie provincial wheat yields based on precipitation and potential evapotranspiration. Canadian fournal of Plant Science 53, 17-30.

Williams, J.R., Renard, K.G. \& Dyke, P.T. 1983. EPIC: A new method for assessing erosions effect on soil productivity. Fotmmal of Soil and Water Conservation 38, 381-384.

Wischmeier, W.H. \& Smith, D.D. 1978. Predicting rainfall erosion losses - a guide to conservation planning. Agricultural Handbook No. 537, USDA, Washington.

Wright, L.E., Zitman, W., Young, K. \& Googins, R. 1983. LESA. Agricultural land evaluation and site assessment. Fournal of Soil and Water Conservation 38, 82-86.

Wright, P.L. 1977. On the application of numerical taxonomy in soil classification for land evaluation. ITC Fournal 1977 3, 482-510.

\title{
WOFOST: a simulation model of crop production
}

\author{
C.A. van Diepen ${ }^{1}$, J. Wolf ${ }^{2}$, H. van Keulen ${ }^{3} \&$ C. Rappoldt ${ }^{4}$
}

\begin{abstract}
The WOFOST simulation model is a tool for analysing the growth and production of field crops under a wide range of weather and soil conditions. Such an analysis is important first to assess to what extent crop production is limited by the factors of light, moisture and macro-nutrients, and second to estimate what improvements are possible. The theoretical concept of a production situation, as modelled by WOFOST, is explained, as is the hierarchy of potential production and water-limited and nutrient-limited production situations in the analysis. The organization of the computer files in the model, the structure of the FORTRAN source program and the available standard sets of data are described briefly.
\end{abstract}

The functions of the most important program sections are discussed. The model can be implemented on many kinds of computers. It can be used on its own, for sitespecific studies of agricultural production potentials. But it can also be coupled to Geographic Information Systems for regional studies, or be used as a data generator for regional agro-economic models. The data on climate, soil and crop, needed for the calculations with WOFOST are specified. However, the general scarcity of comprehensive

${ }^{1}$ Netherlands Soil Survey Institute (STIBOKA), PO Box 98, 6700 AB Wageningen.

${ }^{2}$ Centre for World Food Studies (CWFS), Wageningen.

${ }^{-3}$ Centre for Agrobiological Research (CABO), PO Box 14, 6700 AA Wageningen.

${ }^{4}$ Department of Theoretical Production Ecology, Agricultural University, PO Box 14,6700 AA Wageningen. datasets forms a major constraint for the widespread use of the model in land evaluation.

\section{INTRODUCTION}

WOFOST is the acronym for WOrld FOod STudies. It is the name of a model for simulating the growth of crops and was developed by the Centre for World Food Studies in Wageningen, the Netherlands, in cooperation with the Agricultural University and the Centre for Agrobiological Research (CABO). The version of the model described here is called WOFOST4.1, which is the standard version for use on microcomputers (van Diepen et al., 1988). The model describes the growth and production of annual crops in physical terms determined by crop species, soil type, 


\section{MAIZE YIELD VAR IABILITY}

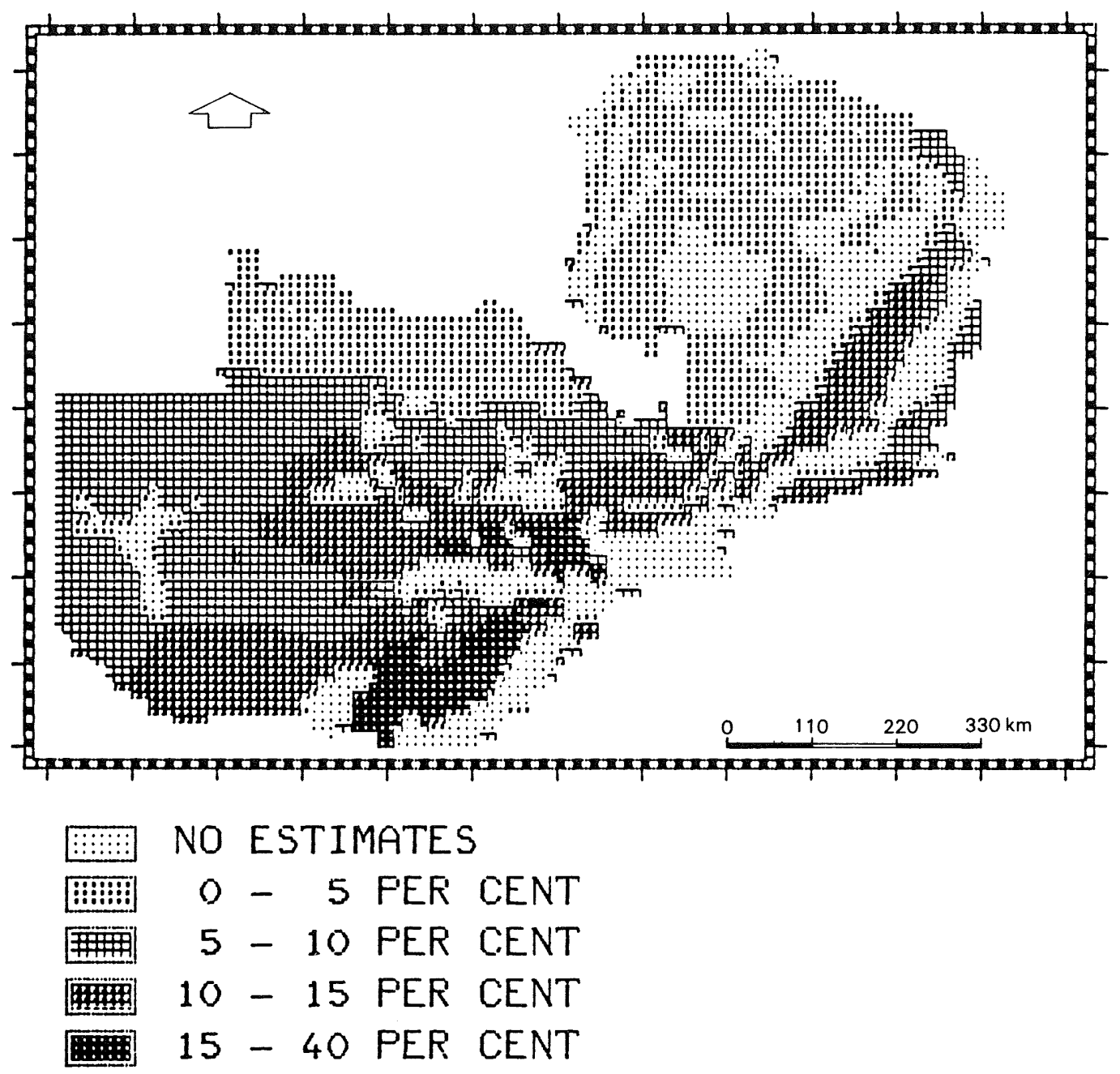

Fig. 1. Map of variability (coefficient of variation; per cent) in calculated water-limited grain yields of maize in Zambia.

hydrologic conditions and weather during the growing season. In principle, the model is applicable anywhere where crops are produced although the model has been developed primarily for agriculture in the tropics.

\section{OBJECTIVE}

The WOFOST model is designed for calculating the agricultural production potential for selected combinations of crop, soil and climate. The calculated theoretical yields allow one to evaluate the relative importance of the principal constraints to crop production, such as light, temperature, water, and the macro-nutrients nitrogen, phosphorus and potassium. This information is used to assess reasonable combinations of inputs needed for attaining certain target yields.
SCALE

\section{Geographic scale}

The modelling procedure takes no account of geographical scale as it is applied basically as a point analysis. Its application to areas relies on the selection of representative points, followed by spatial aggregation or interpolation. The output of the WOFOST model is intended mainly for national and regional planning, but the procedure can just as well be used at more detailed levels.

\section{Time-scale}

WOFOST models one growing season from emergence to maturity. Crop growth and soil water balance are described with a time resolution of one day, and the nutrient uptake is calculated for the whole growing season at once. 


\section{CONCEPTS}

WOFOST calculates crop yields under three principal growth constraints. This results in three theoretically defined situations that are hierarchically ordered according to increasing analytical complexity. They are:

PS1 Potential production: crop growth is limited by light and temperature regime only. Water and nutrient supply are taken to be optimum.

PS2 Water-limited production: moisture supply may limit crop growth. Nutrient supply is taken to be optimum.

PS3 Nutrient-limited production: the soil nutrient supply is introduced as a growth-limiting factor. Nitrogen, phosphorous and potassium are considered as the most constraining macro-nutrients for crop growth.

Other factors could be introduced such as the influence of weeds, pests and diseases, and the effectiveness of farm operations on crop yields. However, WOFOST does not yet allow for these. With respect to practical farming, PS1 indicates the production ceiling for irrigated farming, PS2 for rainfed farming and PS3 for farming without fertilizer application. PS2 also indicates whether irrigation or drainage is needed to realize a potential yield. Running PS2 for different water management scenarios allows evaluation of their effects on crop yields. Finally, PS3 indicates how much fertilizer should be applied to realize the PS1 and PS2 yields. Actual yields on farms are usually less than calculated theoretical yield. Most farmers in the tropics operate below the PS3 level. The difference in yield may be due to the influence of growth conditions and limitations not considered in the model.

The methodological aspects of the WOFOST model, are comprehensively described by van Keulen \& Wolf (1986). The analysis of nutrient-limited production is described in more detail by Janssen et al. $(1986,1988)$. The procedure for the calculation of the $\mathrm{CO}_{2}$ assimilation rate has been taken from the SUCROS model.

\section{PROGRAM STRUCTURE AND ORGANIZATION OF FILES}

The standard microcomputer version of WOFOST comprises source files, data files and executable files (Table 1). WOFOST is divided into modular sections and subsections. This makes it easy to use. Each section corresponds to a FORTRAN subroutine, the subsections are distinguished for editorial convenience only, and their numbers are used in the documentation as paragraph numbers. A summary of all sections is shown in Table 2 . The functions of the most important sections are described below. For a detailed program description see van Diepen et al. (1988).

Four FORTRAN files WMAIN41, APPLE, NUTRIE and WOSUB are the heart of WOFOST. The first three files correspond with the first three program sections and the file-WOSUB-is a grouping of the remaining 23 -other sections.
The standard data files of the model contain data for 22 crops (mainly tropical), 12 soil types (basically texture classes of the 'Staringreeks'; Wösten, Bannink \& Beuving, 1987 ), and 37 weather stations (situated mainly in the tropics). Table 3 gives a listing of the datasets on file. These data files can be expanded with new data for as many crops, soils or climates as required.

WOFOST is supplemented by three auxiliary programs. All the files are contained on two floppy discs (DS, DD), labelled 'source files' and 'run files', respectively (Table 1).

\section{THE FUNCTIONS OF THE PROGRAM SECTIONS}

Section 1 - Program WMAIN41

The flow of the program is organized in the main routine WMAIN41, which allows a single simulation run. In WMAIN41 the user is requested to specify the input data, partly by selecting data from files and partly by typing them on keyboard. Then the input and output files are opened, data are read from the input files through calls to reading subroutines (sections $4,5,6$ ), the output control parameters are set and the routines for the calculation of crop yields are called (sections 2, 3).

\section{Section 2 - Subroutine APPLE}

The simulation subroutine APPLE (Agricultural Production Potential in Land Evaluation) is basically a crop growth model coupled to a soil water balance model. In the crop growth model, the net daily dry matter increase is calculated as a result of assimilation and respiration. This dry matter is partitioned to the major plant organs: roots, leaves, stems, and storage organs. The rates of these processes and the partitioning pattern are determined by the momentary crop status and its response to controlling enviromental conditions. The crop status for a given day is characterized by model variables such as green leaf area, biomass, and stage of phenological development. The crop growth curve and resulting yield are found by integrating the daily dry matter increase, partitioned to the plant organs, over the total crop growth period.

With respect to the water balance, the user has to choose between simulating with or without groundwater influence in the root zone. The function of the soil water balance is to calculate how much water can be taken from the soil by the crop. This is done on the basis of average water content in the root zone for each day of the growth period. The crop will use less water if the soil is either too dry or too wet. In both situations the transpiration rate is reduced, which leads to a concurrent reduction in assimilation rate. In addition, the soil water balance is interesting for its own sake. Therefore, the daily rates for each term of the soil water balance are cumulated to establish the seasonal balance. Subroutine APPLE calls several other subroutines for the manipulation if-elimatic data (sections $7,8,9$ ) and for calculating of processes (sections 10 through 15). 
Table 1. List of files of WOFOST 4.1 on floppy discs

Floppy disc 'Run files'

File name

MAKEMENU EX

PRNF EXE

WOFOST EXE

MENU DAT

SOIL41 DAT

CROP41 DAT

CLIM41 DAT

REALRD DAT

kbytes Description

21.6 This command file produces a list of names of available datasets, i.e. file MENU.DAT.

22.9 This command file allows printing of the calculation results in file WOFOST.OUT in an orderly way.

114.4 This command file allows the interactive use of the WOFOST model.

2.3 List of names of available datasets for crops, soils and climates.

5.3 Physical soil data for 12 soil types (Staringreeks).

23.7 Crop data for 22 crop species or cultivars.

24.8 Monthly climatic data of 37 weather stations.

7.8 Measured daily rainfall data, to be provided by user. REALRD.DAT requires about 6 kbytes of data for 2 years of rainfall; for 10 years this becomes 20 kbytes.

Floppy disc 'Source files'

$\begin{array}{llrl}\text { File name } & \text { kbytes } & \text { Description } \\ \text { MAKEMENU } & \text { FOR } & 1.2 & \\ \text { REALRAIN } & \text { FOR } & 1.2 & \\ \text { REALRAIN } & \text { EXE } & 35.6 & \begin{array}{l}\text { This command file produces a dummy file REALRD.DAT, } \\ \text { filled with zero's for the specified number of }\end{array} \\ & & & \begin{array}{l}\text { years. } \\ \text { PRNF }\end{array} \\ \text { WMAIN41 } & \text { FOR } & 1.5 & \\ \quad \text { FPPLE } & \text { FOR } & 11.1 & \text { These four files form together the simulation } \\ \text { NUTRIE } & \text { FOR } & 31.9 & \text { program of about 92 kbytes long. After compilation } \\ & 13.6 & \text { of the four files they are linked into one executable } \\ \text { WOSUB } & \text { FOR } & 35.1 & \text { file WOFOST.EXE. }\end{array}$

Table 2. List of sections (FORTRAN routines) of WOFOST41 and their function

\begin{tabular}{|c|c|c|}
\hline Section & Function & Called by \\
\hline 1 WMAIN41 & main program & \\
\hline 2 APPLE & simulation of potential or water-limited production & WMAIN41 \\
\hline 3 NUTRIE & $\begin{array}{l}\text { calculates nutrient-limited yields and nutrient } \\
\text { requirements }\end{array}$ & WMAIN41 \\
\hline 4SOILRD & reads soil data from file & WMAIN41 \\
\hline 5 CROPRD & reads crop or cultivar data from file & WMAIN41 \\
\hline 6 CLIMRD & reads climatic data from file & WMAIN41 \\
\hline 7 INTERP & $\begin{array}{l}\text { calculates daily weather data through interpolation } \\
\text { between monthly averages }\end{array}$ & APPLE \\
\hline 8RNREAL & reads daily rainfall data from file & APPLE \\
\hline 9 RNGEN & rainfall generator & APPLE \\
\hline 10 PENMAN & calculates daily potential evapo(transpi)ration & APPLE \\
\hline 11 TOTASS & calculates daily total gross assimilation & APPLE \\
\hline 12 RADIAT & $\begin{array}{l}\text { calculates the fluxes of photosynthetically active } \\
\text { radiation }\end{array}$ & TOTASS \\
\hline 13 ASSIM & calculates gross assimilation rate & TOTASS \\
\hline 14 ASTRO & calculates day length & APPLE \\
\hline 15 SUBSOIL & calculates capillary rise or percolation & APPLE \\
\hline 16 AFGEN & performs linear interpolation in AFGEN tables & several \\
\hline 17 GAMMA & generates gamma-distributed numbers & RNGEN \\
\hline 18 LIMIT & defines upper and lower limits for certain variables & several \\
\hline 19 RANDOM & random number generator & RNGEN \\
\hline 20 SWEAF & calculates fraction of easily available soil water & APPLE \\
\hline $22 \mathrm{MENU}$ & $\begin{array}{l}\text { displays on screen from file MENU.DAT lists of soils, } \\
\text { crops and climates available in the data files }\end{array}$ & WMAIN41 \\
\hline 23 PAUZE & requests from user to press 'Return' to continue & several \\
\hline 24 SKIP & skips lines in sequential file & several \\
\hline 25TABRD & reads datain an AFGEN table & several \\
\hline 26TEXT & used for output text manipulation & APPLE \\
\hline
\end{tabular}


Table 3. Datasets in standard data files

\begin{tabular}{|c|c|c|}
\hline \multicolumn{2}{|c|}{ WEATHER STATIONS IN CLIM41.DAT } & \multirow{2}{*}{$\begin{array}{c}\text { SOIL TYPES IN SOIL41.DAT } \\
\text { Medium to coarse sand (05) }\end{array}$} \\
\hline BOGRA (006) & BDESH & \\
\hline CHITTAGONG (306) & BDESH & Fine sand $(\mathrm{B} 1+01)$ \\
\hline DACCA $(009)$ & BDESH & Loamy fine sand $(\mathrm{B} 2+02)$ \\
\hline BOBO-DIOULASSO & BFASO & Very loamy fine sand $(\mathrm{B} 3+03)$ \\
\hline DORI & BFASO & Fine sandy loam $(B 4+04)$ \\
\hline OUAGADOUGOU & BFASO & Silt (015) \\
\hline OUAHIGOUYA & BFASO & Light loam $(B 7+08)$ \\
\hline $\mathrm{HO}$ & GHANA & Loam $(B 8+09)$ \\
\hline KUMASI & GHANA & Heavy loam $(010)$ \\
\hline NAVRONGO & GHANA & Clay loam $(\mathrm{B} 10+011)$ \\
\hline TAMALE & GHANA & Clay $(\mathrm{B} 11+012)$ \\
\hline ABIDJAN & IVOOR & Heavy clay $(\mathrm{B} 12+013)$ \\
\hline BOUAKE & IVOOR & \\
\hline KORHOGO & IVOOR & CROPS IN CROP41.DAT \\
\hline MAN & IVOOR & Barley \\
\hline TABOU & IVOOR & Cassava \\
\hline ELDORET & KENYA & Chickpea \\
\hline GALOLE & KENYA & Cotton \\
\hline GARISSA & KENYA & Cowpea \\
\hline KERICHO & KENYA & Field bean \\
\hline KISUMU & KENYA & Groundnut \\
\hline KITALE (AIRPORT) & KENYA & Maize \\
\hline MACHAKOS SCHOOL & KENYA & Millet, bulrush \\
\hline MOLOPIJR & KENYA & Mungbean \\
\hline MOMBASA (TOWN) & KENYA & Pigeonpea \\
\hline NAIROBI (DAG.CORNER) & KENYA & Potato (late cv.) \\
\hline BAMAKO & MALI & Rapeseed \\
\hline SEGOU & MALI & Rice HYV-IR8 \\
\hline SIKASSO & MALI & Sorghum \\
\hline DE BILT & NETHERLAND & Soybean \\
\hline NIAMEY AERO & NIGER & Sugarbeet \\
\hline CHANTHABURI & THAIL & Sugarcane \\
\hline CHIANG MAI & THAIL & Sunflower \\
\hline KHONKAEN & THAIL & Sweet potato \\
\hline LAMPANG & THAIL & Tobacco \\
\hline LOP BURI & THAIL & Wheat, spring \\
\hline SURAT THANI & THAIL & \\
\hline CAMBRIDGE & UK & \\
\hline PARIS & FRANCE & \\
\hline SCHLESWIG & $\mathrm{BRD}$ & \\
\hline
\end{tabular}

Section 3 - Subroutine Nutrie

Where nutrients limit production it is calculated from the information on uptake of nitrogen, phosphorus and potassium provided by the user and the nutrient concentrations in plant organs and the harvest index resulting from the crop growth simulation. Next, the amounts of fertilizer needed to reach potential and water-limited yields are calculated, making use of the fertilizer recovery fraction (supplied by the user).

\section{Other sections}

The names and functions of the sections 4 to 26 , all contained in file WOSUB.FOR are given in Table 2. They include-routines for reading data from files, for handling data on climate and weather, for calculating rates of $\mathrm{CO}_{2}$ assimilation-and-of evapotranspiration, for-calculating water flux, and general service routines.
With respect to rainfall, the user may choose between real historical or artificial, mathematically generated daily rain data. The procedure for generating rainfall in routine RNGEN is based on Geng, Penning de Vries \& Supit (1986). Each time a call to RNGEN is made, a full year's daily rainfall data is generated on the basis of monthly data. The use of the rainfall generator allows the calculation of time series of water-limited yields and yield variability.

FUNCTION AFGEN (section 13) is used to interpolate between points of a function defined by pairs of values. AFGEN tables consist of up to 15 data pairs.

\section{INPUT PARAMETERS}

For a simulation run the user first chooses the crop species, climate and soil type for which the corresponding sets of data are called from standard data files. Then the user must provide some site specific information, such as initial 
moisture conditions, depth of groundwater, physical properties of the soil surface, and data on soil fertility, which are, not included in these files, and specify the starting date (the date of emergence or transplanting).

The standard data files are generally not changed, but of course the user may edit them provided the file structure is maintained.

\section{Climate data}

The model uses the monthly climatic data of the CLIM41.DAT file and converts them to daily values for the simulation procedure. The file contains minimum and maximum air temperature, irradiation, humidity, wind speed, monthly rainfall and number of rainy days. Instead of monthly rainfall the user may use daily rainfall from file REALRD.DAT.

\section{Soil profile data}

For the simulation of water-limited production only two soil layers (the rooting zone and the subsoil) are distinguished. Variables to be specified by the user are soil type (i.e. soil texture class), maximum rooting depth, and presence of groundwater table with its initial depth.

\section{Soil physical data}

The soil physical characteristics defined for each type in the SOIL41.DAT file are: soil moisture characteristics, and soil hydraulic conductivity as function of soil moisture tension. These standard soil data of the 'Staringreeks' are not universally valid and their applicability should be carefully evaluated, at least with regard to the field capacity concept and the amount of available soil moisture. A check on the validity of the standard soil conductivity data is usually difficult because of a lack of measured data. Important properties related to the surface conditions, such as the non-infiltrating fraction of rain and surface water storage capacity, are more site specific and should therefore be specified by the user.

\section{Soil fertility data}

Data on soil fertility include the base uptake of nitrogen phosphorus and potassium from unfertilized soil and the recovery fractions of $\mathrm{N}-, \mathrm{P}-$, and $\mathrm{K}$-fertilizers. They have to be specified by the user. The base uptake is the nutrient uptake by a reference crop (e.g. maize) with a growth cycle of 120 days. For other crops the base uptake is related to the length of their growth cycle. These data can be derived from detailed fertilizer experiments or estimated from chemical soil data according to the QUEFTS system (Janssen et al., 1986, 1988). Special constraints such as acidity, salinity, toxicities or micro-nutrient deficiencies are not considered in the model.

\section{Crop data}

For each crop the CROP41.DAT file specifies the crop data needed for the simulation of its growth. They include initial dry weight, life span of leaves, properties that determine assimilation and respiration rates, rate of phenological development, death rates, fractions of assimilates partitioned to plant organs, and the minimum and maximum nutrient concentrations per plant organ. The length of the growth cycle is the only crop characteristic that can be interactively adjusted by the user.

\section{OUTPUT}

WMAIN41 allows the user to modify the output specifications to suit specific requirements. The standard output of the model is shown in Table 4. For a given combination of soil, crop and climate the output is split up by production situation in three parts. The relevant input parameters are shown in the heading of each part.

For the potential production situation, simulation results are given for each tenth day of the growth cycle. The variables listed are dry weights of living leaves, stems and storage organs, leaf area index, development stage, rooting depth, crop transpiration rate, gross assimilation rate, maintenance respiration rate, and total above ground biomass. For the water-limited production situation, the list of crop variables is followed by components of the soil water balance such as actual transpiration and evaporation rates, soil moisture content, surface water storage and amount of water stored in the soil, or groundwater depth. After finishing the simulation of water-limited production, two summarized water balances are given, one for the whole system, and one for the root zone only. Finally, a summary is given of the calculated potential, water- and nutrientlimited yields, harvest indices and fertilizer needs.

\section{LIMITATIONS}

\section{Limitations due to model structure}

The accuracy of the model is limited by assumptions by simplifying the growth process and by ignoring some of the growth determining factors.

The time-step of one day does not allow a correct simulation of processes having a smaller time resolution, such as water infiltration into the soil, runoff, and the day and night rhythm of the assimilation, respiration and transpiration processes in plants. The same is true for the use of a two layer soil profile, which does not allow the simulation of a moisture gradient within the root zone which reduces the accuracy of the calculations of the rates of evaporation, transpiration and percolation. No growth-limiting factors other than light, temperature, water, nitrogen, phosphorus and potassium are considered, and for the sake of simplicity the interactions between moisture and nutrient supply are not taken into account. 
Table 4. Example of standard output of the WOFOST model. The abbreviations are listed in Table 5 (opposite).

WOFOST.OUT/Version 4.1 Last update May 1987 VARP $1=1.20$ VARP $2=1.00$

\section{POTENTIAL CROP PRODUCTION}

\begin{tabular}{|c|c|c|c|c|c|c|c|c|c|c|c|c|}
\hline \multicolumn{4}{|c|}{ KHONKAEN } & \multirow{2}{*}{$\begin{array}{l}\text { THAIL } \\
\text { WSO }\end{array}$} & \multicolumn{6}{|l|}{ Maize } & \multicolumn{2}{|c|}{ Start day 227} \\
\hline DAY & ID & WLV & WST & & LAI & DVS & $\mathrm{RD}$ & $\mathrm{T}$ & GASS & MRES & DMI & TAGP \\
\hline 227 & 0 & 7. & 5. & 0. & 0.03 & 0.00 & 10. & 0.01 & 7.9 & 0.5 & 5.3 & 12. \\
\hline 237 & 10 & 82. & 50. & 0 . & 0.27 & 0.22 & 22. & 0.05 & 76.6 & 4.8 & 51.1 & 132. \\
\hline 247 & 20 & 659. & 404. & 0. & 1.90 & 0.44 & 34. & 0.25 & 385.4 & 36.3 & 248.2 & 1063. \\
\hline 257 & 30 & 2045. & 1484. & 0. & 5.32 & 0.66 & 46. & 0.38 & 586.9 & 112.4 & 335.2 & 3528. \\
\hline 267 & 40 & 3011. & 3199. & 0. & 7.16 & 0.88 & 58. & 0.41 & 619.4 & 179.7 & 307.9 & 6366. \\
\hline 273 & 46 & 3241. & 433 j. & 125. & 7.33 & 1.00 & 65. & 0.42 & 624.3 & 208.6 & 292.2 & 8059. \\
\hline 277 & 50 & 3288. & 4933. & 462. & 7.23 & 1.09 & 70. & 0.42 & 625.3 & 223.5 & 283.7 & 9188. \\
\hline 287 & 60 & 3126. & 5802. & 2205. & 6.65 & 1.31 & 71. & 0.42 & 616.8 & 249.1 & 263.5 & 11941. \\
\hline 297 & 70 & 2942. & 5738. & 4631. & 6.17 & 1.53 & 71. & 0.40 & 574.6 & 258.7 & 227.4 & 14420. \\
\hline 307 & 80 & 2829. & 4688. & 6742. & 5.88 & 1.74 & 71. & 0.39 & 510.8 & 247.3 & 189.7 & 16531. \\
\hline 317 & 90 & 1756. & 3831. & 7879. & 3.32 & 1.94 & 71. & 0.32 & 174.5 & 174.5 & 0.0 & 17668. \\
\hline 320 & 93 & 1382. & 3605. & 7879. & 2.51 & 2.00 & 71. & 0.27 & 0.0 & 0.0 & 0.0 & 17668. \\
\hline \multicolumn{13}{|c|}{ SUMMARY: } \\
\hline \multirow{2}{*}{\multicolumn{2}{|c|}{$\begin{array}{c}\text { DAYS } \\
46\end{array}$}} & TWRT & TWLV & TWST & TWSO & TAGP & \multirow{2}{*}{\multicolumn{2}{|c|}{$\begin{array}{l}\text { GASST } \\
41464\end{array}$}} & MREST & HINDEX & TRC & WUSE \\
\hline & & 1590. & 3934. & 5855. & 7879. & 17668. & & & 14391. & 0.45 & 167. & 29.6 \\
\hline
\end{tabular}

\section{WATER LIMITED CROP PRODUCTION, Year 1}

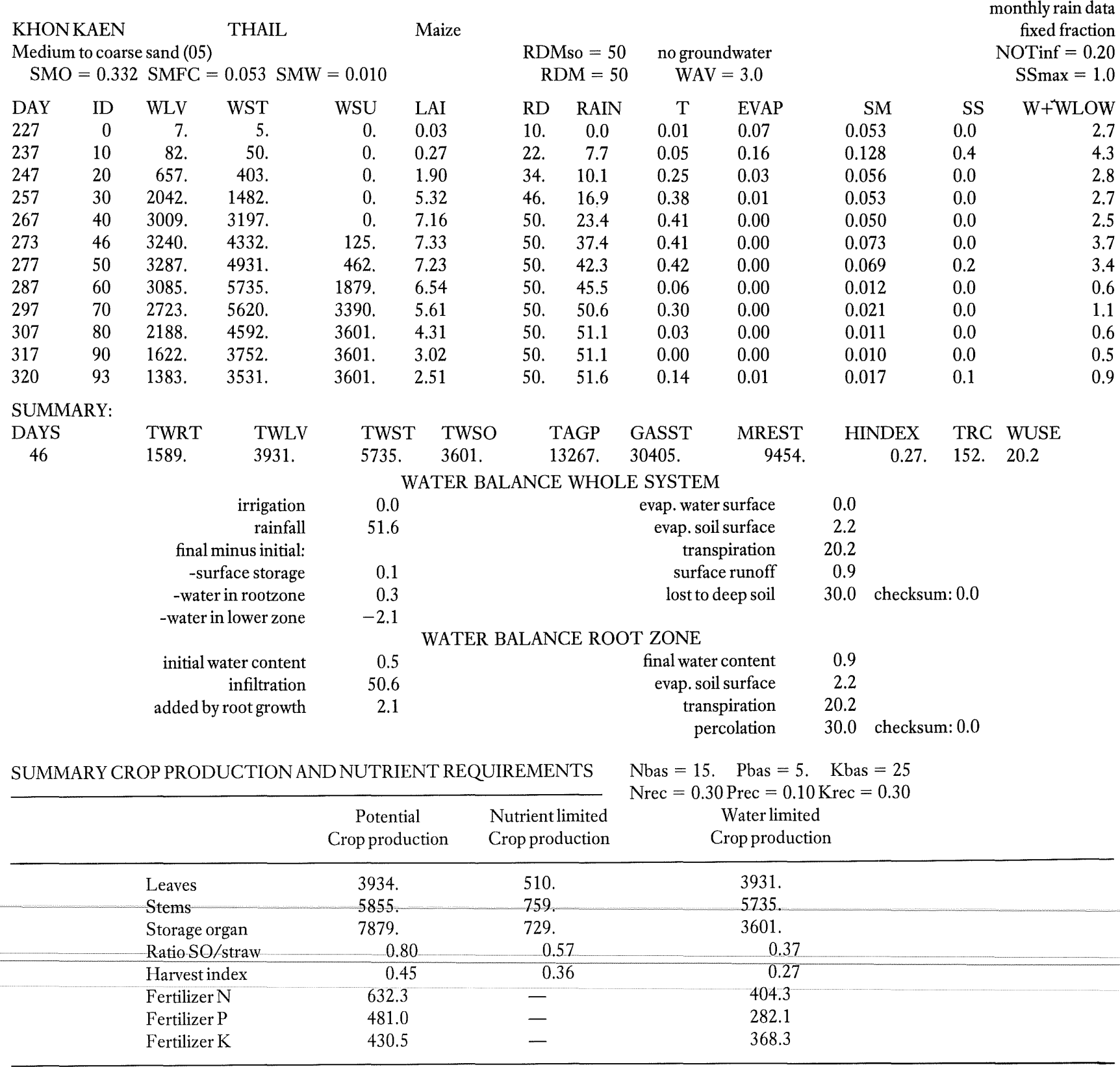


Table 5. Abbreviations used in the standard of the WOFOST model

\begin{tabular}{|c|c|c|}
\hline Symbol & Description & Unit \\
\hline VARP & $\begin{array}{l}\text { crop variety parameter, indicating the length of the } \\
\text { growth period in relation to that of the standard crop }\end{array}$ & - \\
\hline VARP1 & crop variety parameter for pre-anthesis growth & - \\
\hline VARP2 & crop variety parameter for post-anthesis growth & - \\
\hline DAY & day number in the Julian calendar, from 1 to 365 & d \\
\hline ID & number of days since emergence & d \\
\hline WLV & dry weight of living leaves & $\mathrm{kg} \mathrm{ha}^{-1}$ \\
\hline WST & dry weight of living stems & $\mathrm{kg} \mathrm{ha}^{-1}$ \\
\hline WSO & dry weight of storage organs & $\mathrm{kgha}^{-1}$ \\
\hline LAI & leaf area index & haha ${ }^{-1}$ \\
\hline DVS & $\begin{array}{l}\text { development stage of the crop } \\
(0.0 \text { at emergence, } 1.0 \text { at anthesis, } 2.0 \text { at maturity) }\end{array}$ & - \\
\hline $\mathrm{RD}$ & effective rooting depth & $\mathrm{cm}$ \\
\hline $\mathrm{T}$ & actual transpiration rate & $\mathrm{cm} \mathrm{d}^{-1}$ \\
\hline GASS & $\begin{array}{l}\text { actual gross assimilation rate of the canopy (in mass } \\
\text { units of carbohydrates) }\end{array}$ & $\mathrm{kgha}^{-1} \mathrm{~d}^{-1}$ \\
\hline MRES & maintenance respiration rate & $\mathrm{kg} \mathrm{ha}^{-1} \mathrm{~d}^{-1}$ \\
\hline DMI & rate of dry-matter increase of the crop & $\mathrm{kgha}^{-1} \mathrm{~d}^{-1}$ \\
\hline TAGP & $\begin{array}{l}\text { total above-ground biomass production, dry weight of } \\
\text { living and dead plant organs }\end{array}$ & \\
\hline DAYS & $\begin{array}{l}\text { number of days since emergence to anthesis and to } \\
\text { maturity, respectively }\end{array}$ & $\mathrm{d}$ \\
\hline TWRT & total dry weight of roots (dead and living) & $\mathrm{kgha}^{-1}$ \\
\hline TWLV & total dry weight of leaves (dead and living) & $\mathrm{kgha}^{-1}$ \\
\hline TWST & total dry weight of stems (dead and living) & $\mathrm{kgha}^{-1}$ \\
\hline TWSO & total dry weight of storage organs & $\mathrm{kg} \mathrm{ha}^{-1}$ \\
\hline TAGP & total above-ground dry weight (dead and living) & $\mathrm{kgha}^{-1}$ \\
\hline GASST & total gross assimilation, in carbohydrates & $\mathrm{kgha}^{-1}$ \\
\hline MREST & total maintenance respiration & $\mathrm{kgha}^{-1}$ \\
\hline HINDEX & harvest index & \\
\hline TRC & $\begin{array}{l}\text { transpiration coefficient (ratio of water use and dry } \\
\text { matter production) }\end{array}$ & $\mathrm{kg} \mathrm{kg}^{-1}$ \\
\hline WUSE & water use, or total transpiration during growth cycle & $\mathrm{cm}$ \\
\hline RDMso & maximum rooting depth allowed by the soil & $\mathrm{cm}$ \\
\hline NOTinf & non-infiltrating fraction or rainfall & - \\
\hline $\mathrm{SM} \phi$ & soil moisture content at saturation & $\mathrm{cm} \mathrm{cm}^{-3}$ \\
\hline SMFC & soil moisture content at field capacity & $\mathrm{cm} \mathrm{cm}^{-3}$ \\
\hline SMW & soil moisture content at wilting point & $\mathrm{cm} \mathrm{cm}^{-3}$ \\
\hline RDM & maximum rooting depth & \\
\hline WAV & $\begin{array}{l}\text { initial amount of water in total rootable } \\
\text { zone (amount of water above wilting point) }\end{array}$ & $\mathrm{cm}$ \\
\hline SSmax & surface storage capacity & $\mathrm{cm}$ \\
\hline RAIN & total rainfall since crop emergence & $\mathrm{cm}$ \\
\hline $\mathrm{T}$ & actual transpiration rate & $\mathrm{cm} \mathrm{d}^{-1}$ \\
\hline EVAP & actual evaporation rate from soil or water surface & $\mathrm{cm} \mathrm{d}^{-1}$ \\
\hline SM & soil moisture content in root zone & $\mathrm{cm}^{3} \mathrm{~cm}^{-3}$ \\
\hline SS & surface storage, depth of water layer & $\mathrm{cm}$ \\
\hline W+WLOW & amount of water in rootable zone & $\mathrm{cm}$ \\
\hline $\mathrm{W}$ & amount of water in rooted zone & $\mathrm{cm}$ \\
\hline WLOW & $\begin{array}{l}\text { amount of water in rootable zone below the momentarily } \\
\text { rooted depth }\end{array}$ & $\mathrm{cm}$ \\
\hline Nbas & $\begin{array}{l}\text { actual supply of nitrogen from the soil during the } \\
\text { crop growth period }\end{array}$ & $\mathrm{kg} \mathrm{ha}^{-1}$ \\
\hline Pbas & actual supply of phosphorus from the soil & $\mathrm{kgha}^{-1}$ \\
\hline Kbas & actual supply of potassium from the soil & $\mathrm{kgha}^{-1}$ \\
\hline Nrec & recovery fraction of applied fertilizer nitrogen & - \\
\hline Prec & recovery fraction of applied fertilizer phosphorus & - \\
\hline Krec & recovery fraction of applied fertilizer potassium & - \\
\hline
\end{tabular}


Limitations due to data constraints

Despite the simplifications, the model still requires many data, and the general scarcity of data seriously limits its use as a predictive tool in land evaluation and for planning. For instance, a simulation run of water-limited production requires more soil physical data than a routine soil survey can provide. Moreover, many of the environmental data used pertain to average conditions and do not allow the evaluation of the effects of their erratic nature and of extreme conditions. The data constraint is also a problem for the further development of the model because complete and detailed datasets are needed for model validation. Such datasets may be either measured experimental data or data generated by more detailed, validated models. However, very few datasets appear to be available.

\section{COMPUTERS AND PROGRAMLANGUAGE}

WOFOST can be implemented on any IBM-PC or IBMAT compatible machine using an IBM FORTRAN compiler. After a few changes WOFOST can also be implemented on a VAX/VMS system using a FORTRAN77 compiler. The FORTRAN is as general as possible to allow implementation on other machines with a minimum of program modifications.

\section{ASSOCIATED SYSTEMS}

\section{Geographic Information System}

A Geographic Information System (GIS) is used for the construction of a geographic data base. This allows soil and climate maps to be digitized. The GIS provides the facilities to input, combine, extract and display spatial data. The GIS can be used to select all unique soil-climate combinations in a country. These can be sent to the WOFOST model to run simulations for all combinations for a given crop and to produce country maps of calculated yield levels for that crop. This procedure has been followed for the calculation of water-limited yields and yield variability of maize in Zambia by Wolf, van Diepen \& Immerzeel
(1987). The maize yield variability shown in Fig. 1 is based on simulated yields over 20 years for each soil-climate combination and is calculated as the coefficient of variation.

\section{Agro-economic model}

The yield levels generated with the WOFOST model are accompanied by the amount of inputs required for actually achieving these yields. These yield and input data can be used in a linear programming model for agricultural production in a region, to establish regional production potentials under a given set of socio-economic constraints. Such an approach can be applied in land-use planning (van Keulen et al., 1987).

\section{REFERENCES}

Geng, S., Penning de Vries, F.W.T. \& Supit, I. 1986. A simple method for generating daily rainfall data. Agricultural and Forest Meteorolog' 36, 363-376.

Janssen, B.H., Guiking, F.C.T., van der Eijk, D., Smaling, E.M.A. \& van Reuler, H. 1986. Quantitative evaluation of fertility in tropical (QUEFTS). Mimeograph, Agricultural University, Wageningen.

Janssen, B.H., Guiking, F.C.T., van der Eijk, D. Smaling, E.M.A., Wolf, J. \& van Reuler, H. 1988. A system for quantitative evaluation of soil fertility and the response to fertilizers. Proceedings Symposium Land qualities in space and time, Wageningen (in press).

van Diepen, C.A., Rappoldt, C., Wolf, J. \& van Keulen, H. 1988. Crop gromth simulation model WOFOST version 4.1, documentation. SOW-8801. Centre for World Food Studies, Wageningen.

van Keulen, H. \& Wolf, J. (Eds) 1986. Modelling of agricultural production: weather, soils and crops. Simulation Monographs, PUDOC, Wageningen.

van Keulen, H., Berkhout, J.A.A., van Diepen, C.A., van Heemst, H.D.J., Janssen, B.H., Rappoldt, C. \& Wolf, J. 1987. Quantitative land evaluation for agro-ecological characterization. In: (Ed. A.H. Bunting), pp. 185-197, Agricultural environments, characterization, classification and mapping, CAB International.

Wolf, J., van Diepen, C.A. \& van Immerzeel, C.H. 1987. Monitoring agro-ecological resources using remote sensing and simulation (MARSproject). A study on the limitations to maize production in Zambia using simulation models and a geographic information system. Centre for World Food Studies, Wageningen.

Wösten, J.H.M., Bannink, M.H. \& Beuving, J. 1987. Waterretentieen doorlatendheidskarakteristieken van boven-en ondergronden in Nederland: de Staringreeks. STIBOKA rapport 1932, ICW rapport 18. 